\title{
Unintended Population Consequences of Policies
}

\author{
Barbara A. Anderson \\ University of Michigan
}

\begin{abstract}
Unintended population consequences of policies stem from three sources: (1) A policy overshoots its original goal; (2) different policies conflict, so that the implementation of one policy inhibits implementation of another policy; (3) negative consequences of a policy are unforeseen, or are anticipated but judged unlikely to be severe or considered less important than the positive aims of the policy. Examples from Singapore, South Africa, Italy, the U.S., and the former Soviet Union are discussed.
\end{abstract}

KEY WORDS: population policy, fertility; migration.

\section{INTRODUCTION}

This article discusses three sources of unintended population consequences of policies. First, a policy can be more effective than anticipated and overshoot its original goal. After that, reversing the earlier trend can be very difficult. Second, there can be a conflict between different policies. The implementation of one policy can make it impossible or difficult to achieve the goals of another policy. Sometimes this inherent conflict is recognized, but at other times it goes unrecognized for a long time. Third, there can be unintended negative consequences of a policy, although the consequences could have been anticipated. Examples of each of these kinds of unintended consequences are discussed and some overall implications for policy and demographic change are examined.

Please send correspondence to Barbara A. Anderson, Population Studies Center, University of Michigan, 426 Thompson Street, Box 1248, Ann Arbor, MI 48106-1248; e-mail: barba@umich.edu. 


\section{OVERSHOOTING OF GOALS AND INEXACT TARGETING}

In the 1960s and 1970s many less-developed countries implemented policies designed to reduce fertility. It is impossible to overshoot a goal in a mortality reduction policy, since lower mortality is virtually always considered desirable, but it can be easy to overshoot a fertility reduction goal, since the goal is not ever-lower fertility but usually a fertility level that, in combination with mortality, yields a low but positive population growth rate.

When fertility threatens to fall below replacement level, policies are often implemented to increase fertility. Sometimes the goal is to increase fertility among all segments of the population, but at times a general pronatalist policy is too blunt an instrument. This can happen when the state wants to encourage childbearing among the highly educated, among members of a particular ethnic group, or among people in a particular region of the country. Fine-tuning a pro-natalist policy can be extremely difficult. This section discusses policies to reduce fertility in Singapore, followed by policies to increase fertility in Singapore, especially among ethnic Chinese and among highly educated women.

When a policy overshoots its goals, the result is not completely unintended, since this result was always a possible outcome of the policy. In this case, the consequences were only unintended in the sense that when the fertility reduction policies were implemented, the government did not anticipate needing to implement a pro-natalist policy after only a few years.

\section{Fertility Policies in Singapore Since 1966}

Fertility in Singapore began to fall in 1957 (Fawcett \& Khoo, 1980, p. 554). In 1966, Singapore implemented policies intended to lower fertility further (Cheung, 1998, p. 155). The relative success of the fertility reduction program in Singapore, in comparison to programs in other countries with similar goals, has been widely noted (Fawcett \& Khoo, 1980; Lee, Alvarez \& Palen, 1991; Saw, 1975). Figure 1 shows the total fertility rate (TFR $)^{1}$ in Singapore 1950-2000 (United Nations, 2001).

These policies included a large education campaign, with information about contraceptives and about the benefits to the family of having no more than two children. Following Fawcett (1979, pp. 7-9), there were also five kinds of disincentives to childbearing:

(1) Maternity policies: Fees for pre-natal care and delivery fees increased with parity, while maternity leave was not given for third and later births. There was no delivery fee if the woman was sterilized after delivery; 


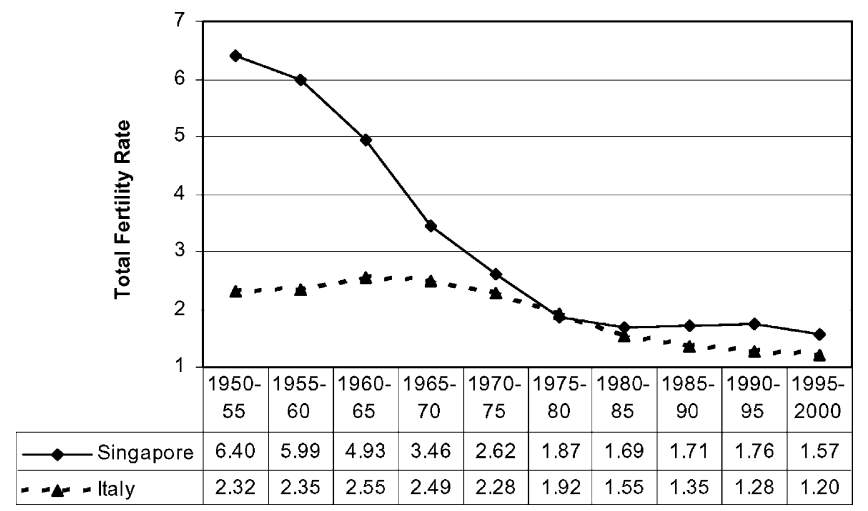

FIGURE 1. Total fertility rate in Singapore and Italy 1950-2000.

(2) Education policies: Priority in choice of school is given to first and second children if a parent was sterilized before age 40 and if no more than three children were born;

(3) Income tax policies: Income tax deductions are lower or not given for the third and later children;

(4) Housing policies: Large families no longer have priority in obtaining larger units in public housing, and those families with no more than three children are allowed to sublet rooms;

(5) Other policies: Government employees get paid leave after sterilization, and abortion and sterilization are heavily subsidized (Fawcett, 1979; Fawcett \& Khoo, 1980; Lee et al., 1991).

These fertility-reduction policies were successful, but their impact was differential by ethnic group. Figure 2 shows the total fertility rate 19571996 in Singapore by ethnic group (Cheung, 1998, p. 160). The very rapid fertility decline, especially among Chinese, is striking. In addition, moreeducated women responded to the incentives to reduce fertility more than did less-educated women.

In some ways, these policies succeeded too well. By 1980, fertility was below replacement ${ }^{2}$ for Singapore as a whole. This low fertility level in Singapore was due to the low fertility of ethnic Chinese; fertility was above replacement for the Malay and Indian populations. By 1983, concern about low fertility generally was growing, but there was concern especially about the low fertility of university-educated women (Lee et al., 1991, p. 66) and of ethnic Chinese (Cheung, 1998, p. 158). 


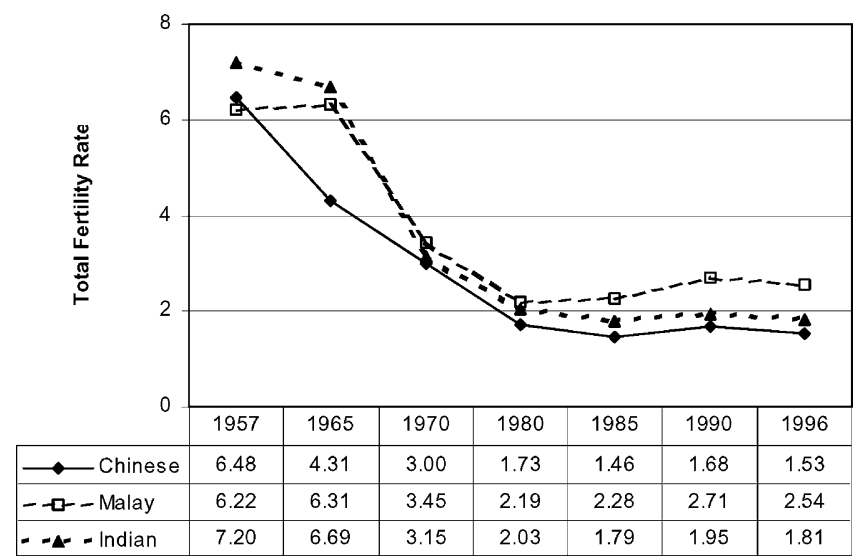

FIGURE 2. Total fertility rate by ethnic group in Singapore 1957-1996.

In 1984, policies were implemented with the intention of increasing fertility in specific groups. A program was instituted to give priority access to high-quality public schools to the children of women who had attended a university and who had at least three children (Lee et al., 1991, p. 67). Also in 1984, a governmental Social Development Unit was established to encourage men and women who were university graduates to marry (Cheung, 1998, pp. 159-160; Lee et al., 1991, p. 67). The very selective nature of the program is emphasized by the implementation of a program of cash payments to poor and poorly-educated women who became sterilized (Lee et al., 1991, p. 67; Saw, 1985, p. 2).

Now, in 2004, the Singapore government continues to seek ways to increase population growth. On the website of the Ministry of Community Development and Sports, of which the Social Development Unit is a part, there appears the text (Singapore, Ministry of Community Development and Sports, 2004):

No matter how globalised we become, Singapore needs a core of Singapore citizens. Do you have any good suggestions on how we can set up a conducive environment to support parenthood and ensure a future generation of core Singaporeans? Call us at 1800-2585812 or click on the link above to send in your views.

After a slight increase in the total fertility rate from 1985 to 1995, it declined to a new low of 1.57 in the 1995-2000 period (Figure 1). The 
Singapore government found out that fertility was not a faucet that could be turned on and off.

\section{CONFLICTS BETWEEN DIFFERENT POLICIES}

Sometimes the goals of one proposed policy directly conflict with the goals of another proposed policy. Controversy ensues about which of the two goals should be pursued. At other times, progress toward the goals of two policies conflict. Unintended demographic consequences can result from a policy that was not intended to influence population policies at all (see also Ting, this issue, and $\mathrm{O}^{\prime}$ Connor, this issue). In this section, examples of such policy conflicts in the areas of fertility and migration are discussed.

Regionally Differentiated Fertility Policy in the Soviet Union in the 1970s and 1980s

In the late 1970s, the total fertility rate in the Soviet Union was moderate at 2.3. However, this was the result of at or below replacement fertility in the European part of the Soviet, combined with much higher fertility in Soviet Central Asia. Figure 3 indicates the difference between fertility in the European and non-European parts of the Soviet Union by showing the total

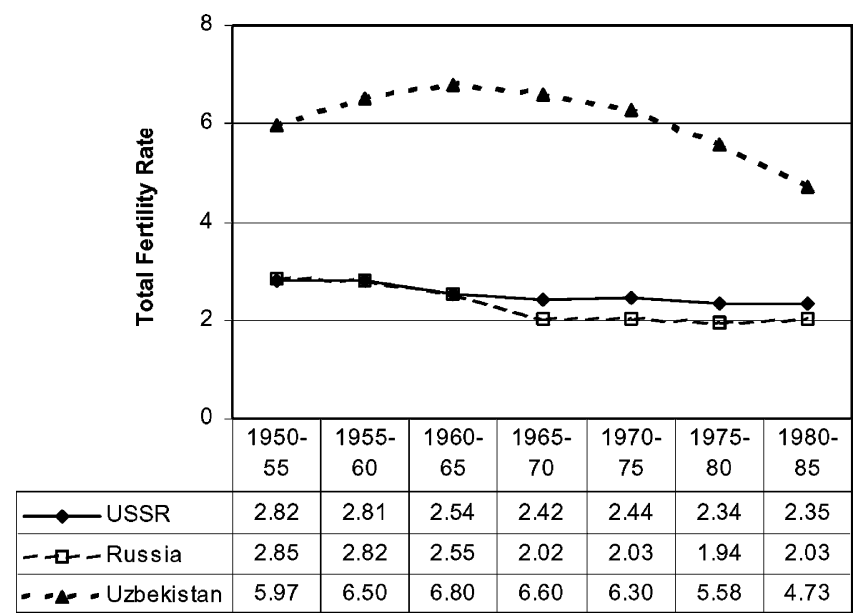

FIGURE 3. Total fertility rate in the USSR, Russia and Uzbekistan 19501985. 
fertility rate in the largest European republic, Russia, and in the largest nonEuropean republic, Uzbekistan (United Nations, 2001).

As a result of the regional fertility differential, there was a developing labor surplus in Central Asia, and a labor shortage in central European Russia. There were policies to promote long-term migration from Central Asia to European Russia, but they met with little success, and there was little support for moving a large amount of industry from European Russia to Central Asia.

The Soviet Union had pro-natalist policies in place since 1944, but these policies did not differentiate by region of the country or rural-urban residence; further, they came into effect at very high parity, and subsidized only extremely poor families (Defosses, 1981; Heer, 1977) and, thus, tended to further increase the regional fertility differential.

Increasingly, some policy-makers and demographers thought that fertility policy should be differentiated by region or by rural-urban residence, and many thought that fertility incentives should be developed to encouraged women to have a moderate (not low) level of fertility, rather than only rewarding a high level of fertility (Jones \& Grupp, 1987; Weber \& Goodman, 1981).

While many demographers from Russia advocated a differentiated policy in order to approach equalization of fertility levels in different parts of the Soviet Union and to encourage women who were having two children to have three children, other demographers, especially those from Central Asia, criticized such regional proposals as discriminatory and implicitly genocidal (Heer, 1977; Jones \& Grupp, 1987; Weber \& Goodman, 1981). Basic principles were in conflict.

At the Soviet Communist Party Congress in 1981, a limited fertility policy was implemented that encouraged second and third births. This policy took effect throughout the Soviet Union by 1983. The policy provided a payment of 50 rubles for second and third births, paid maternity leave of one year (eventually extended to three years), and defined a family with three children or more as a "large family," which allowed them priority in housing and other services (Weber \& Goodman, 1981; Zakharov \& Ivanova, 1996).

Probably as a result of these new pro-natalist policies, fertility in the European part of the Soviet Union increased for a while, with the TFR in Russia rising from 2.03 in 1980-1985 to 2.13 in 1985-1990, and then falling to 1.52 in 1990-1995. Zakharov and Ivanova (1996) argue, however, that the rise in fertility in Russia would have been temporary even if the Soviet Union had not dissolved, since the policies to promote second and third births mainly affected the timing of these births rather than resulting in 
a larger desired family size. It is unknown whether these policies to promote moderate rather than low fertility would have had a greater effect if they had been introduced earlier.

\section{Fertility, Labor Force Participation and Childcare in Italy}

Many European countries have below-replacement fertility and would like to increase childbearing (Chesnais, 1996). Also, in some countries many people, including members of the government, think that it is best for mothers of young children to stay home to care for their children.

These two aims can conflict. If women need to make a choice between having a child and working for pay, this can result in both lower female labor force participation and lower fertility than if women thought they could successfully pursue both roles. Many of these same low-fertility countries have aging populations and would like to raise female labor force participation because they face an increasing old age dependency ratio. Policies that discourage both childbearing and female labor force participation present a severe problem for these countries.

For individual women in a given society there is often a negative relation between childbearing and labor force participation, because of the competing role demands women face as mother and worker (Bernhardt, 1993, pp. 27-28). However, Sundstrom and Stafford (1991) found a strong positive relationship between the total fertility rate and the female labor force participation rate in 20 developed countries. Rindfuss and Brewster (1996) argue that the essential issue in developed countries is role incompatibility: that if women can successfully combine the roles of mother and worker, then both fertility and female labor force participation will be relatively high. Thus, within any given country, the less conflict between the demands of the roles of mother and worker, the higher both fertility and female labor force participation. Consistent with this view, Apps and Rees (2001, p. 1) find that countries that "support families through improved availability of alternatives to domestic childcare, rather than through direct child payments, are likely to have both higher female labor supply and higher fertility."

Italy is perhaps an extreme example of the policy and value conflict described above. With below-replacement fertility since the mid-1970s, the Italian government has sought to increase fertility. Figure 1 shows the total fertility rate in Italy 1950-2000. The decline in fertility has been gradual but sustained since the mid-1960s.

Among six Western European countries (Austria, U.K., Ireland, Italy, Netherlands and West Germany) in 1988, Italian respondents express the 
strongest support for the centrality of children (Jones \& Brayfield, 1997). In a study of 34 industrialized countries, Treas and Widmer (2000) found the largest gender difference in attitudes about the appropriateness of women combining work and motherhood in Italy, with Italian men being much more conservative.

Private childcare in Italy is rare, and there are limited public childcare spaces available for children under age 3, meaning that Italian families cannot rely on being able to obtain a space in public childcare for a young child. In addition, public childcare is open at most 7.5 hours per day. The limited public childcare hours are also a problem because in most of Italy, there is little part-time work available for women (Del Boca, Locatelli \& Vuri, 2003).

The inconvenience and lack of availability of childcare in Italy make the combination of having a small child and working full-time especially difficult for women. Traditionally, in Italy, it was acceptable for a close relative, such as the child's grandmother, to care for a small child. From a study in 1998, $72.9 \%$ of working mothers with a child under age 3 used informal childcare, such as a relative (Del Boca, et al., 2003). However, increased geographic mobility means that the proportion of Italian workingage families who live close to the older generation has declined. Del Boca (2002) found that the availability of public childcare, and the availability of a relative who could care for a young child, were more important in women's decisions to work for pay than was the cost of childcare. The cost of childcare was only important in those locations in which there was not a shortage of public childcare spaces.

In an analysis of the relation of fertility and female labor force participation in Italy, using panel data on married women for 1991-1995, Del Boca (2002) found that availability of childcare and availability of part-time work were related to both the probability that a woman would work for pay and the probability that the woman would have a child. It seems that in Italy attitudes and policies that encourage women to stay home to care for their young children have contributed to depressing both fertility and female labor force participation below the levels they likely would have attained if childcare had been available in a way that was more compatible with the needs of mother who work for pay.

\section{Brain Drain in South Africa}

There has been much concern in South Africa about net emigration from the country, especially among skilled professionals, such as medical doctors. At the same time, the South African public expresses strong 
antagonism toward immigrants (Southern African Migration Project, 2001c). This anti-immigrant sentiment is often encouraged by the South African press (South African Migration Project, 2000a).

Figure 4 shows legal immigration, emigration and net migration rates to South Africa 1950-1999 (South African Institute of Race Relations, 2001, pp. 66-67). The image of the brain drain in South Africa is of skilled workers fleeing the country. However, the shift from net immigration to net emigration is mainly due to the decline in the immigration rate; the emigration rate changed more slowly than the immigration rate.

South Africa has the best economy in Africa and would be an attractive destination for professionals in other African countries. There have been concerns in other parts of Africa about a possible "brain drain" of skilled workers and professionals to South Africa (Saasa, 1996; Southern African Migration Project, 2002, p. 3). However, motivated by the desire to protect good jobs in South Africa for South Africans, it is extremely difficult for a non-South African to get a work permit or obtain permanent residency. These barriers to immigration or work by foreigners have prevented any substantial brain drain from the rest of Africa to South Africa from occurring (Crush, 1999; Southern African Migration Project, 2000b).

South Africa passed new immigration legislation in 2002 (South Africa, 2002), which acknowledges that border control cannot totally stop illegal migration to South Africa. The law depends mainly on rules requiring employers to determine that all of their employees have proper documen-

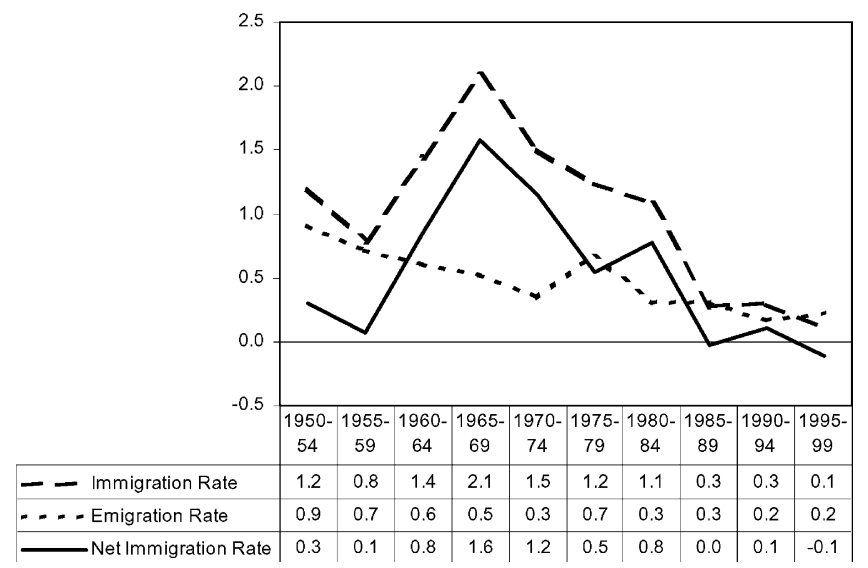

FIGURE 4. Immigration, emigration and net immigration rates per 1000 population, South Africa legal migrants 1950-1999. 
tation to work in South Africa. This approach concentrates on regulating who takes good jobs (jobs with an employer who pays wages); it is less concerned with illegal migrants who work on their own account, such as in trade.

In discussion of the planned legislation, it was clear that a top priority was protecting South African jobs for South Africans. As in other countries, for skilled jobs, the White Paper on Migration stated that if there is a shortage of qualified South Africans, the first preference goes to persons from other Southern African countries, then to persons from elsewhere in Africa, then to persons from the rest of the world (South Africa, Department of Home Affairs, 1999). However, the 2002 Immigration Act does not incorporate these preferences (Southern African Migration Project, 2001a, 2001b).

Thus, through a combination of policies, South Africa seems to be choosing to accept a brain drain of skilled workers in order to achieve the goal of protecting good jobs in South Africa for South Africans.

\section{ANTICIPATED BUT UNINTENDED CONSEQUENCES}

Sometimes negative population consequences of a policy are foreseen as possible but either the positive policy aims are viewed as having priority, or there is disagreement about the extent to which possible negative consequences will occur. In this section, some negative consequences of immigration law and immigration enforcement policy in the U.S. are discussed.

Immigration Law and Enforcement in the United States Since 1986

The Immigration Reform and Control Act of 1986 placed responsibility on employers not to employ workers who did not have legal status in the U.S. The U.S. Congress anticipated that discrimination against applicants who appeared foreign would likely increase. Analysis of data from a Government Accounting Office survey of employers found that $10 \%$ of employers changed the way they treated applicants who appeared foreign (Lowell, Teachman \& Jing, 1995; U.S. Government Accounting Office, 1990). Lowell et al., (1995) further found that those employers who changed their practices also tended to hire a disproportionately small number of Hispanics, suggesting that discrimination had increased against Hispanics who could legally work in the U.S. 
In 1993, the U.S. Government substantially increased its efforts to reduce illegal migration from Mexico, especially in areas that had been heavily used for this purpose. Between 1994 and 2000, Border Patrol apprehensions on the Southwest order increased by $68 \%$, followed by a decline in 2001 of 25\% (Cornelius, 2001).

Cornelius (2001) argues that some of the major effects of the new policies were that illegal migrants who had already entered the U.S. tended to stay longer (due to the increased danger of apprehension while crossing); and new migrants redirected their border crossing choices to previously less-used border areas. But these new areas were in difficult terrain, which posed substantial risks to the migrants. Between 1996 and 2000 deaths of illegal border-crossers in the southwest increased by 474\%, from 87 in 1996 to 499 in 2000. The increased deaths were mainly from drowning and heatrelated causes, such as dehydration and sunstroke.

In both of these areas related to illegal migration, the main consequences were foreseen. Congress in considering IRCA recognized that increased discrimination against Hispanics, whether in the United States legally or not, would increase. Regarding the stricter enforcement procedures at the border, Cornelius (2001, p. 667) writes:

In addition to rechanneling the flow of illegal migrants, the current US border enforcement strategy has significantly raised the cost and physical risks associated with illegal entry. These should not be treated as "unintended" consequences, since they were a integral part of the INS's "prevention through deterrence" strategy from its inception.

\section{CONCLUDING REMARKS}

We have discussed examples of different ways in which unintended demographic consequences of policy occur. The three types of unintended consequences proceed from least unintended to most unintended. Even in the examples discussed there is some overlap of types.

Table 1 lists the examples discussed and classifies them by type. If "unintended" means completely unanticipated, few policy consequences are actually unintended. Often unintended population consequences are viewed as negative. To avoid these negative consequences, it is not enough for policy-makers to be aware of the negative population consequences. 


\section{TABLE 1}

Sources of Unintended Population Consequences

\begin{tabular}{|c|c|c|c|}
\hline Policy & $\begin{array}{l}\text { Overshot } \\
\text { Goals }\end{array}$ & $\begin{array}{l}\text { Conflict } \\
\text { Between } \\
\text { Policies }\end{array}$ & $\begin{array}{c}\text { Anticipated but } \\
\text { Unintended } \\
\text { Consequences }\end{array}$ \\
\hline Singapore Fertility Policy & Primary & Secondary & \\
\hline $\begin{array}{l}\text { Differentiated Fertility Policy } \\
\text { in the USSR }\end{array}$ & Secondary & Primary & \\
\hline Fertility, Work \& Childcare in Italy & & Primary & \\
\hline Brain Drain in South Africa & & Primary & \\
\hline $\begin{array}{l}\text { Immigration Law \& Enforcement } \\
\text { in the U.S.A. }\end{array}$ & & & Primary \\
\hline
\end{tabular}

Primary: Main source of unintended consequences.

Secondary: Contributing source of unintended consequences.

In democracies the determination of government policy is a major focus of disagreement among political parties. It is not surprising that different policies are often in conflict, or that there are disagreements about how severe anticipated negative consequences of policies might be. Even in non-democratic states, such as the former Soviet Union, the different positions of various groups in society had some influence on policy (Skilling \& Griffiths, 1971).

Research and analysis can provide better understanding of likely intended and unintended policy consequences, which can help both policy-makers and the public. However, as long as policy-makers do not agree on what policies are desired, and so long as there is little incentive to not implement policies that conflict with each other, the kinds of unintended population consequences of policy discussed in this article are likely to continue to occur.

\section{ACKNOWLEDGMENTS}

The research upon which this paper was based was supported by a Mellon Foundation Grant to the Population Studies Center, University of Michigan; and by National Institutes of Child Health and Human Development Infrastructure Grant HD41028 to the Population Studies Center, University of Michigan. 


\section{ENDNOTES}

1. The total fertility rate at a given date is the number of children that a woman would have if she lived through the childbearing ages having children at each age at the rate in force in that population at that date.

2. Replacement level fertility is the level of fertility, which in combination with age-specific mortality rates would lead to zero population growth in the long term. This means that the net reproduction rate would equal 1.00 . In a low mortality population, this means a total fertility rate of slightly higher than 2.00 .

\section{REFERENCES}

Apps, P., \& Rees, R. (2001). Fertility, female labor supply and public policy, a paper presented at the European Society for Population Economics, June 5, Bilbao.

Bernhardt, E. (1993). Fertility and employment. European Sociological Review, 9, 25-42.

Chesnais, J. -C. (1996). Fertility, family, and social policy in contemporary Western Europe. Population and Development Review, 22, 729-739.

Cheung, P. (1998). Singapore. In Asian Population and Development Association, Comparative study of population policies in Asia-Focus on eight Asian countries. Tokyo: Asian Population and Development Association, pp. 155-160.

Cornelius, W. A. (2001). Death at the border: Efficacy and unintended consequences of US immigration control policy. Population and Development Review, 27, 661-685.

Crush, J. (1999). The discourse and dimensions of irregularity in post-apartheid South Africa. International Migration, 37.

Defosses, H. (1981). Pro-natalism in Soviet law and propaganda. In H. Defosses (Ed.), Soviet population policy: Conflicts and constraint (pp. 95-123). New York: Pergamon.

Del Boca, D. (2002). Do child care costs affect labor supply? Paper ChilD n. 18/2002, Torino: Centre for Household, Income, Labour and Demographic Economics.

Del Boca, D., Locatelli, M., \& Vuri, D. (2003). Child care choices by Italian households. Paper ChilD n. 30/2003, Torino: Centre for Household, Income, Labour and Demographic Economics.

Fawcett, J. T. (1979). Singapore's population policies in perspective. In P. Chen \& J. Fawcett (Eds.), Public policy and population change in Singapore (pp. 3-17). New York: The Population Council.

Fawcett, J. T., \& Khoo, S.-E. (1980). Singapore: Rapid fertility transition in a compact society. Population and Development Review, 6, 549-579.

Heer, D. (1977). Three issues in Soviet population policy. Population and Development Review, 3, 229-252.

Jones, E., \& Grupp, F. (1987). Modernization, value change and fertility in the Soviet Union. Cambridge: Cambridge University Press.

Jones, R., \& Brayfield, A. (1997). Life's greatest joy?: European attitudes toward the centrality of Children. Social Forces 75, 1239-1269.

Lee, S. M., Alvarez, G., \& Palen, J. J. (1991). Fertility decline and pronatalist policy in Singapore. International Family Planning Perspectives 17, 73, 65-69.

Lowell, B. L., Teachman, J. \& Zhongren Jing. (1995). Unintended consequences of immigration reform: Discrimination and Hispanic employment. Demography 32, 617-628.

Neville, W. (1978). The birth rate in Singapore. Population Studies, 32, 113-133.

Rindfuss, R. \& Brewster, K. L. (1996). Childrearing and fertility. Population and Development Review, Fertility in the United States: New Patterns, New Theories, (Supplement 22), 258 289. 
Saasa, O. (1996). Migration and the brain drain. In G. Maasdorp (Ed.), Can South and Southern Africa Become Globally Competitive Economies? London: Macmillan.

Saw, S.-H. (1975). Singapore: Resumption of rapid fertility decline in 1973. Studies in Family Planning, 6, 166-169.

Saw, S.-H. (1985). New population policies for more balanced procreation. Contemporary Southeast Asia, 17, 2.

Singapore, Ministry of Community Development and Sports (2004). Homepage. Website: http://www.mcds.gov.sg/web/home_main.asp. accessed March 6, 2004.

Skilling, H., \& Griffiths, F. (1971). Interest groups in Soviet politics. Princeton: Princeton University Press.

South Africa (2002). Immigration Act. No. 13. Pretoria: Author.

South Africa, Department of Home Affairs (1999). White Paper on International Migration. Pretoria: Author.

South African Institute of Race Relations (2001). South Africa Survey 2000/01. Johannesburg: Author.

Southern African Migration Project (2000a). Writing xenophobia: Immigration and the press in post-apartheid South Africa (Migration Policy Series No. 17). Kingston, Ontario, Canada: Author.

Southern African Migration Project (2000b). The brain gain: Skilled migrants and immigration policy in post-apartheid South Africa (Migration Policy Series No. 20). Kingston, Ontario, Canada: Author.

Southern African Migration Project (2001a). The South African White Paper on international migration: An analysis and critique (Migration Policy Brief No. 1). Kingston, Ontario, Canada: Author.

Southern African Migration Project (2001b). The new South African immigration bill: A legal analysis (Migration Policy Brief No. 2). Kingston, Ontario, Canada: Author.

Southern African Migration Project (2001c). Immigration, xenophobia and human rights in South Africa (Migration Policy Series No. 22). Kingston, Ontario, Canada: Author.

Southern African Migration Project (2002). Thinking about the brain drain in southern Africa (Migration Policy Brief No. 8). Kingston, Ontario, Canada: Author.

Sundstrom, M, \& Stafford, F. (1991). Female labor force participation, fertility, and public policy, Stockholm Research Report in Demography, No. 63, Stockholm University.

Treas, J., \& Widmer, E. (2000). Married women's employment over the life course: Attitudes in cross- national perspective. Social Forces, 78, 1409-1436.

United Nations (2001). World Population Prospects The 2000 Revision. Volume I: Comprehensive tables. New York: Author.

United States Government Accounting Office (1990). Immigration reform: Employer sanctions and the question of discrimination. Washington, D.C.: Author.

Weber, C., \& Goodman, A. (1981). The demographic policy debate in the USSR. Population and Development Review, 7, 279-295.

Zakharov, S. \& Ivanova, E.(1996). Fertility decline and recent changes in Russia: On the threshold of the second demographic transition. In J. DaVanzo (Ed.), Russia's demographic crisis (pp. 36-82). Santa Monica, CA.: RAND. 